DOI: $10.29202 /$ nvngu/2019-1/13

A. Boutemedjet,

M. Bounouala, Dr. Sc. (Tech.), Prof., A. Idres, Dr. Sc. (Tech.), Prof., A. Benselhoub, PhD
Badji Mokhtar University, Annaba-Algeria, e-mail: boutemedjetassia@yahoo.fr

\title{
ASSESSMENT OF DUST POLLUTION RELATED TO GRANITE QUARRY OPERATIONS IN KEF BOUACIDA, ANNABA (ALGERIA)
}

Purpose. Assessment of dust pollution and analysis of aero-particles generated during operations at the quarry of Kef Bouacida aggregates, located in Oued El Aneb Annaba north-eastern of Algeria.

Methodology. Measurement and monitoring of dust fallen, taken from the quarry site allowed identifying the forms and characteristics of the collected particles. These measurements were performed according to the French AFNOR NF X 43-007 standards on measurement of dry atmospheric deposition by the method of platelet deposition.

Findings. The results obtained during the dust fall show that these measures $\left(83.34 \mathrm{~g} / \mathrm{m}^{2} / \mathrm{month}\right)$ are much higher than the reference values of $30 \mathrm{~g} / \mathrm{m}^{2} /$ month in the AFNOR NF-X43-007, to the German standard TA-LUFT $\left(10.5 \mathrm{~g} / \mathrm{m}^{2} /\right.$ month) and the Swiss OPair law $\left(6 \mathrm{~g} / \mathrm{m}^{2} / \mathrm{month}\right)$. For this reason, containment methods and measures intended to limit, prevent and eliminate the consequences of the production on the environment are suggested.

Originality. The evaluation of the adverse effects related to mining production, in particular the nuisance of dust, which can contribute to sensitizing the fight against these negative impacts on the environment, health and safety of the local population, and also increase environmental preservation actions and sustainable development.

Practical value. The reduction of fine particle emissions is the greatest environmental challenge that the Algerian mining faces. The effects assessment of mining of granite on the environment, and the description of the difficulties of dust propagation, can be maintained by reduction measures to fight this nuisance, which poses safety and health problems for staff, accelerates the wear of equipment, and affects the quality of materials, not to mention the inconvenience to residents and farmers. This study is part of the development of environmental protection and conservation of natural resources.

Keywords: Algeria, dust pollution, impact, environment, Kef-Bouacida quarry

Introduction. Algeria has significant potential in the mining sector, which plays an important role for its economic development. Achievements in the field of public works shows that the 2005-2009 program required the use of 70.5 million tonnes of aggregates, 28.25 million tonnes of sands, 8 million tonnes of bitumen and 2.5 million tonnes of bitumen for tonnes of cement used for the realization of the structuring projects in the field of transport, and in particular the realization of the highway project in east-west and that of the high plateaux, the extension of the national road network and the implementation of new railway lines [1].

The Algerian territory has 1146 mining operations in 48 wilayas, including 906 private companies and 240 public farms. Thus, the number of private enterprises has increased due to investment promotion provisions in this area. As a result, with this industrial development, pollution problems are beginning to arise $[2,3]$.

Granite is a gravelly-textured magmatic plutonic rock, characterized by a mineralogical composition of quartz minerals, micas (biotite or muscovite), potassic feldspars (orthoses) and plagioclases. It is a resistant natural material widely used in the construction, paving, decoration and sculpture [4].

However, the standardization of the construction material requires mechanical preparation by means of primary, secondary and tertiary crushing up to a particle size of less than $30 \mu \mathrm{m}$ containing a significant level of fine particles smaller than $20 \mu \mathrm{m}$ deposited on the equipment used.

(C) Boutemedjet A., Bounouala M., Idres A., Benselhoub A., 2019
According to statistics, the production of dust in a crushing station is estimated at between 7 and $84 \mathrm{~g} / \mathrm{m}^{2} /$ month in a radius of 100 to 200 meters; and its nocivity resides in the particle size class between 0.1 and 10 micrometres retained by the pulmonary apparatus [5] [6]. Dusts larger than 10 micrometres are practically stopped by a respirator, which is detrimental to the health of the quarry workers [7, 8].

However aggregates produced in the Kef-Bouacida quarry, are of the graves siliceous category according to the chemical composition of the rock; they generate environmental impacts by dust emissions at all stages of production. In view of the problems that these dusts represent, it has been recommended to install platelets (deposit plate described in standard NF X 43-007) [9], the objective is to control the fallout of dust during the period from January 23 to December 27, 2017. These are thin metal plates made of stainless steel, covered with hydrophobic coating and arranged horizontally in the outside air. Their size is $5 \cdot 10 \mathrm{~cm}\left(50 \mathrm{~cm}^{2}\right.$ of exhibition space).

The dust conducts in the air adhering to the surfaces and coats the platelets. After duration of exposure, chosen according to the site dust conditions, the platelets are washed with solvent to recover the coating and the dust.

The dissolved coating is then removed by filtration, the dusts are dried and weighed, and these dusts can then be processed according to the data to be obtained. These platelets are mainly used for the determination of particulate compounds in the quarry environment, to solve this problem and preserve the surrounding environment; the dust samples taken from the site are sub- 
ject to a physico-chemical characterization to better understand the natural characteristics of the rock and its impact on the environment. Dust can affect the development of agriculture and cause diseases such as silicosis and pneumoconiosis [10]. It is known that granite has interesting properties, including its compressive strength, abrasiveness and high hardness.

The objective of this work is to measure the level of dust generated by the production of aggregates within the Kef Bouacida quarry, using the metal platelet method, and then to analyse the obtained results.

Site description. The Kef Bouacida quarry, which is the subject of this study, is located north-west of the city of Annaba in the east of the country about $600 \mathrm{~km}$ from Algiers (Fig. 1). The Kef Bouacida massif located in the South West in the extension of the outcrops of the Sidi Saadi massifs and the Jebel Sidi Bouguenna massif, covering an area of $5 \mathrm{~km}^{2}$ occupies the upper part of the Oued el Aneb valley.

The Edough Massif is characterized by a complex geological structure consisting of a rock set of Paleozoic, Jurassic, Cretaceous, Paleogenic and finally the Numidian series of the Upper Oligocene.

Materials and Methods. In order to conduct this work and to be able to reach the objectives, we completed a bibliographical synthesis relating to the geology of the Edough massif, as well as description of the soil from coring, and sampling intact, which in turn is used in the manufacture of thin sections for petrographic, mineralogical identification, and chemical, mechanical and geotechnical tests. Generally, the networks of monitoring of the air quality measure airborne particles of aerodynamic diameter less than 10 microns (PM10), for health reasons; the fraction of particles smaller than this value can be inhaled. Particles larger than PM10 are collected at the level of the nasopharyngeal segment and then evacuated by blowing or swallowing. The coarse particles pass this first barrier and penetrate to the tracheobronchial segment; this segment is protected by hair cells and calceiform cells producing mucus [11, 12].

Impact of suspended particles. The reduction of fine particle emissions is the greatest environmental challenge that the Algerian mining faces. This study involves conducting a dust monitoring campaign in Kef Bouacida's quarry. The study concerns the analysis of aero-particles of samples deposited by gravity around the quarry grouping of seven stations. The method of samples collecting is applied according to the French standard which involves the use of metal deposit plates. The most sensitive station, which is that of the jaw crusher treatment until storage and destocking of the finished product, shows a value of $83.34 \mathrm{~g} / \mathrm{m}^{2} /$ month, $\left(2.74 \mathrm{~g} / \mathrm{m}^{2} /\right.$ day $)$ while the limit tolerated by the applied standard is $1 \mathrm{~g} / \mathrm{m}^{2} /$ day.

Presentation of the used method. The method followed is that of metal plates described by the French standard NFX 43-007 (AFNOR) [9]. These stainless steel plates coated with a hydrophobic fixer are devices for collecting dust present in the air. The deposit is then sampled and transferred to a filter for weighing and analysis to estimate the importance of atmospheric deposition.

Equipment. The metal plates are arranged horizontally $1.5 \mathrm{~m}$ from the ground. They are of dimensions $50 \cdot 100 \mathrm{~mm}$ fixed to supports with a length of $2 \mathrm{~m}$, with a ground anchor of $40 \mathrm{~cm}$ and having the AFNOR standard. The particles that are deposited on the plates by gravitation are retained or stabilized by the coating that covers the plates. The coating is defined by the AFNOR standard as a hydrophobic fixer, having the property of fixing the deposited dust (in this study, it is Vaseline).

Monitoring program. The monitoring network sweeping through the polluted area consists of seven sampling areas covering the entire quarry (shown in Fig. 2), which

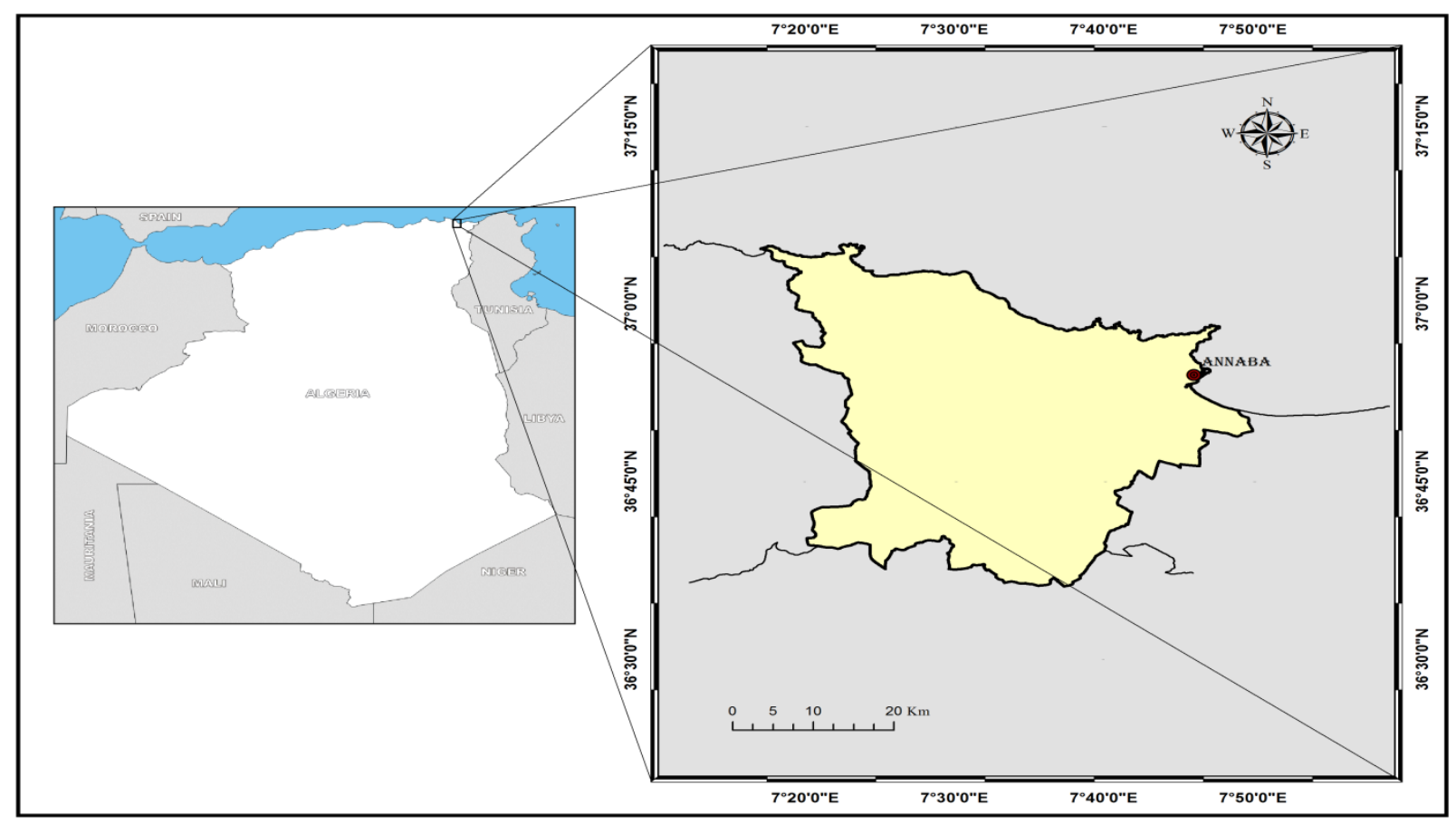

Fig. 1. Geographical location of the study area 
include drilling and blasting (Z1), jaw crusher (Z2), secondary crusher feed pile (Z3), secondary crusher (Z4), storage and destocking finished product (belt conveyor) (Z5), the administration and canteen (Z6) and finally the storage of the product marketed (Z7). The monitoring network was set up throughout the year 2017, in this large follow-up period.

Meteorological data during measurements. Weather plays an important role in the transport and dispersion of air pollutants. Meteorological data were collected from the National Meteorological Office of Annaba during the sampling period, from January 23 to December 27, 2017.

Temperature. The climate of the region is Mediterranean, mild and humid in winter, hot in summer. The cold period is between November and April; the hot period lasts from May to October. The temperature averages are respectively 14 and $23^{\circ} \mathrm{C}$.

Precipitation. Rainfall cleans the atmosphere by driving a part of the dust and pollutants that it contains to the soil. For particles, the effectiveness of this removal decreases with the size of the particles (the larger ones are, the easier it is to clean).In addition, precipitation is still favourable for the dispersion of pollutants, because they cause the mixing of air and therefore cause turbulence and instability of the lower atmospheric layers. The rains are abundant but irregular; the region receives a mean of 100 days of rain a year, distributed between October and February. It snows very little in this part of the country except for the summit of Jebel Edough.

Relative humidity. The humidity of the air is very high, the tension of the water vapour is important because of the proximity of the sea. The hygrometric state is almost constant; it undergoes only slight variations whatever the period.

The winds. Wind is one of the most important meteorological parameters for the transport and dispersion of pollutants. There is an obvious relationship between wind speed and pollutant concentration levels. Pollutant dispersion increases with wind speed and turbulence. A weak wind, therefore, promotes the accumulation of pollutants. Wind speed increases with altitude. The dominant winds are North West-oriented, the wind roses below, which is a synthetic representation of the mean frequencies of the wind directions in groups of speeds, which shows that the winds come mainly from the Northeast, The strongest winds with velocities greater than $8 \mathrm{~m} / \mathrm{s}$ are infrequent, most of the time winds are less than $4.5 \mathrm{~m} / \mathrm{s}$ (Fig. 3).

The first step of the present study is the petrographic and mineralogical identification from the deep drilling technique, going up to $31.55 \mathrm{~m}$ of TP-50 type carried out for the prospection of the granite rock deposit, determining a lithological section of the study area characterized by the presence of a gray-colored pure granite, with a degree of alteration varies between II-IV, 0.92-0.94\% water absorption, a density of $2.49-2.52 \mathrm{~g} / \mathrm{cm}^{3}$, a specific weight of $2.57 \mathrm{~g} / \mathrm{cm}^{3}$ and finally a simple compressive strength of $113-125 \mathrm{MPa}$.

The macroscopic visual description of the samples and the qualitative definition represent a massive structure, rich in quartz, biotite and feldspar. Microscopic observation of the thin sections shows that the rocks are altered and feature a gray-grained texture with black feldspar crystals and white mica of microlitic texture with a facies corresponding to a massive structure with a prismatic flow. The granites of Kef Bouacida are represented by essential minerals, quartz, plagioclase, orthoses, biotites; Secondary minerals are represented by iron oxide, and chlorite (Fig. 4).

As mentioned above, granite has interesting properties, in particular, its compressive strength, abrasiveness and high hardness. The mechanical analyses determined by the Micro-Deval tests consist in measuring the wear

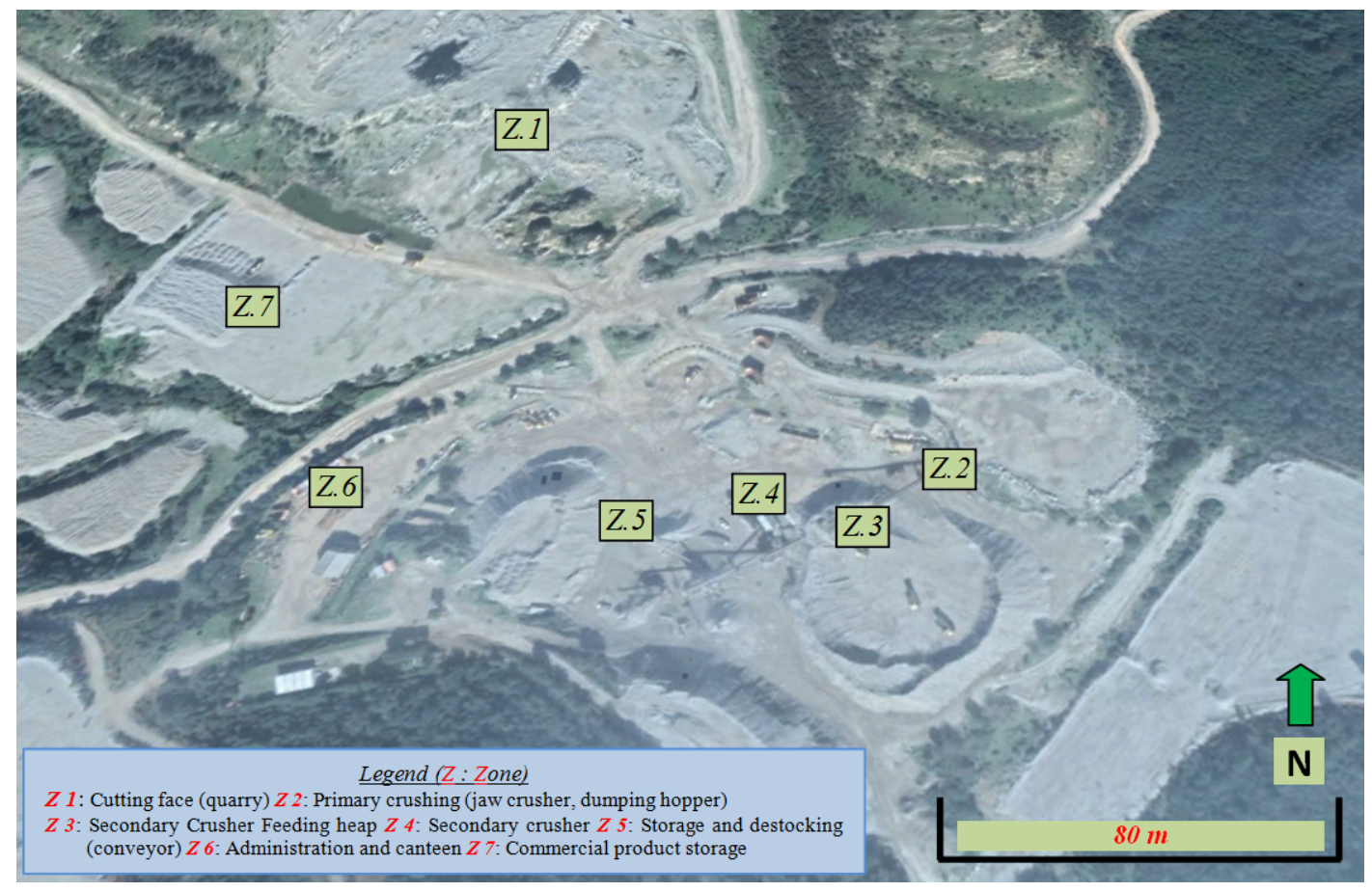

Fig. 2. Location of points measures in the career 

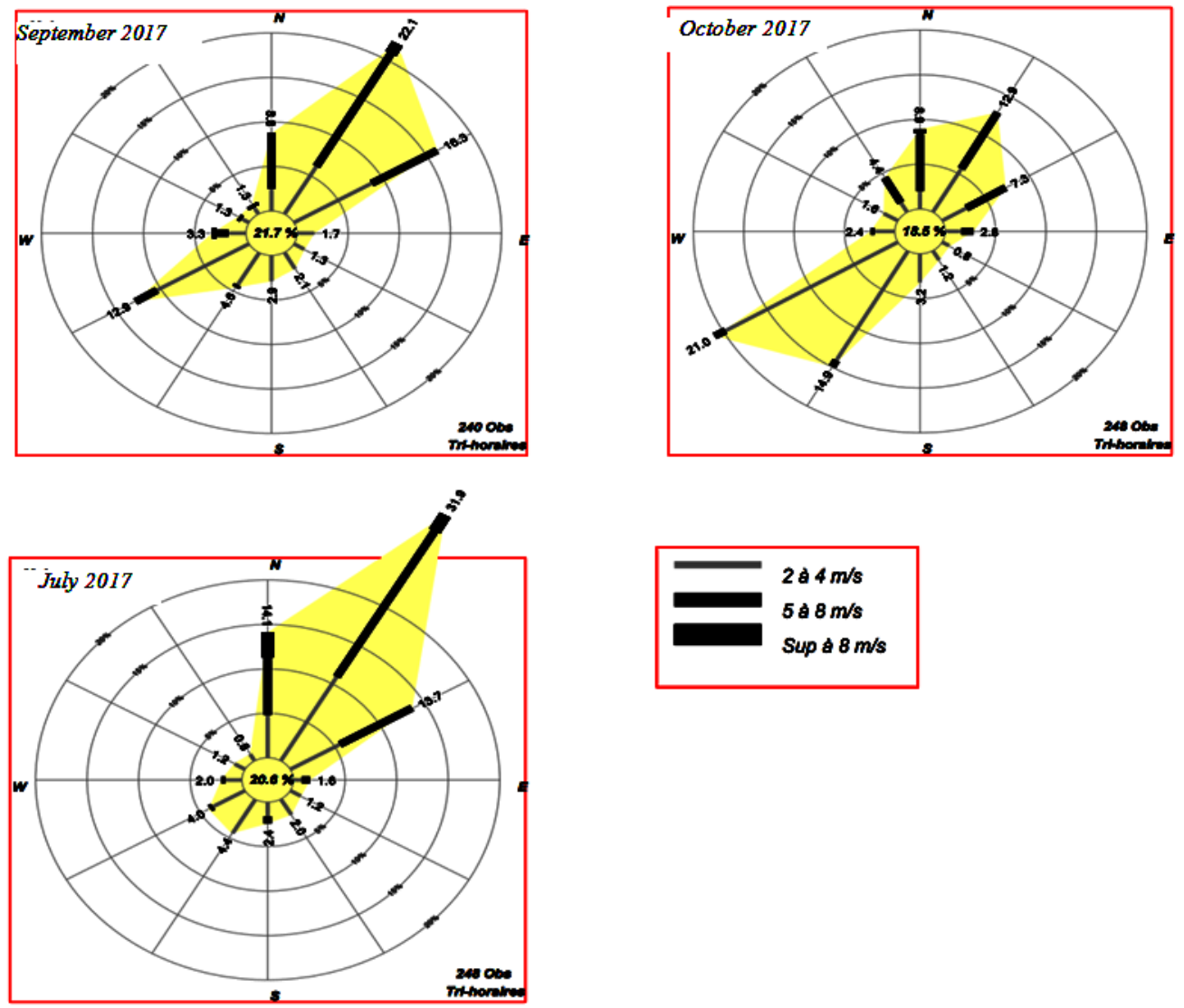

Fig. 3. Frequency of tri-hourly winds during the months of July, September and October. The percentage of calm is indicated in the centre of the rose

resistance of the aggregate sample, according to the standard NF P18-572 and the tests of Los Angeles, the objective is to measure the resistance to shock fragmentation of the elements of a granulate sample (Table 1).
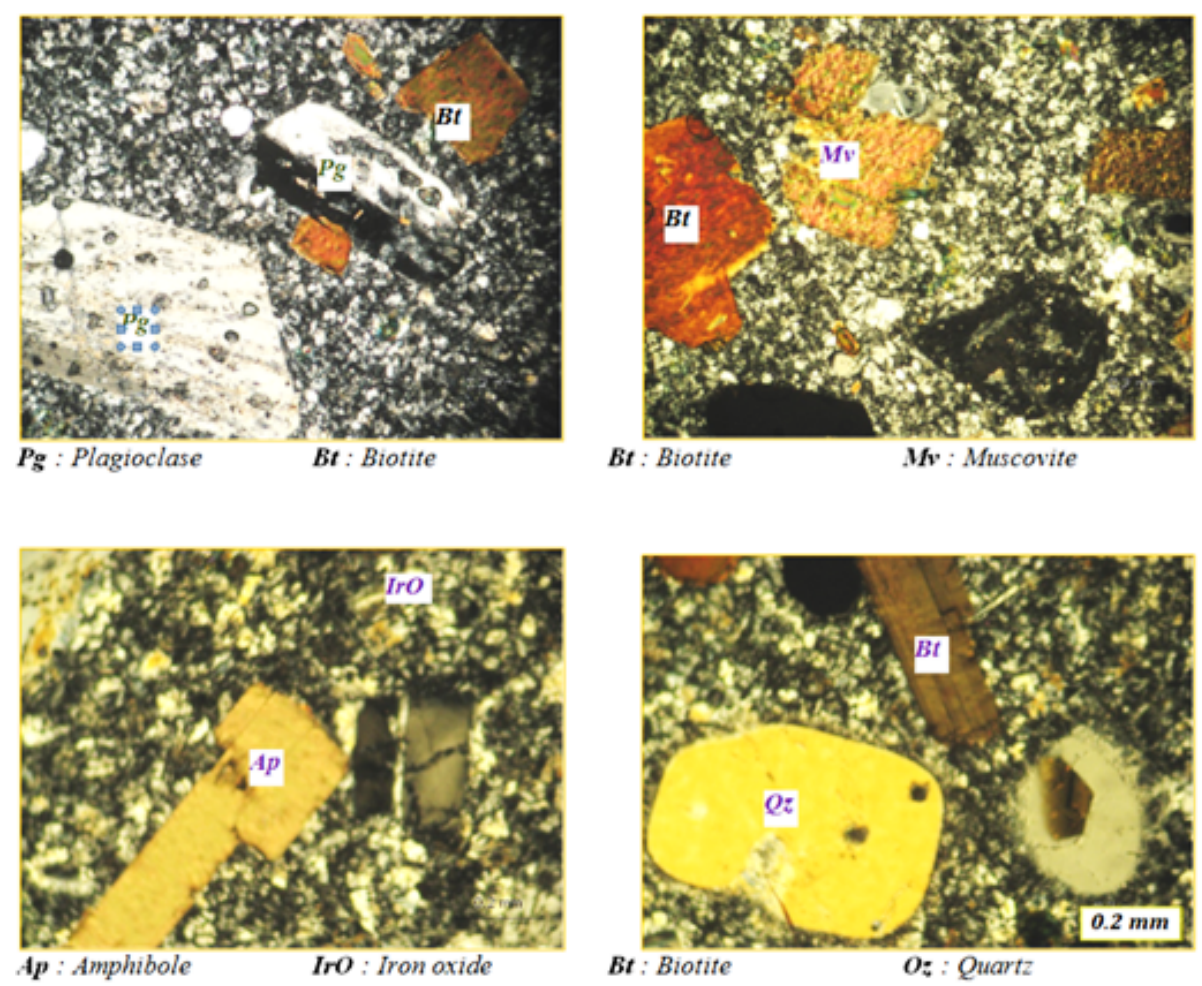

Fig. 4. Microscopic view of thin granite slats 
The analysis by the X-ray fluorescence determines the elemental analysis of a rock sample; results are shown in Table 2.

The results given in Table 2 illustrate that the bedrock is characterized by high levels of $\mathrm{SiO}_{2}$ and $\mathrm{Al}_{2} \mathrm{O}_{3}$ and is low in $\mathrm{K}_{2} \mathrm{O}, \mathrm{CaO}, \mathrm{Na}_{2} \mathrm{O}, \mathrm{Fe}_{2} \mathrm{O}_{3}$ and $\mathrm{SO}_{3}$. Dust enters to the human organism through the respiratory system, the existence of such dust with high concentration may cause a hazardous health effects (irritation of the respiratory tract, chronic bronchitis or irreversible pulmonary fibrosis called silicosis and cancer, and others) [13].

The analysis with X-ray diffraction is shown in Fig. 5; it determines the crystalline composition and shows the presence of all mineralogical phases listed in order of importance: quartz, plagioclase, clay minerals (biotite and muscovite) and amphiboles.
Results and discussion. Figs. 6 and 7 illustrate the evolution and distribution of dust from the seven sampling areas where it is found that zones 5 and 4 record the highest level of dustiness far exceeding the acceptable limit fixed by the AFNOR standards $\left(30 \mathrm{~g} / \mathrm{m}^{2} / \mathrm{month}\right)$, German TA-Luft $\left(10.5 \mathrm{~g} / \mathrm{m}^{2} /\right.$ month) and the Swiss OPair $\left(6 \mathrm{~g} / \mathrm{m}^{2} /\right.$ month). The zone with the lowest level of dust at each sample is Zone 01, which has less than the reference value. This is justified partly by the remoteness of the areas producing the dust (rock treatment) and, on the other part, the blasting work that does not exceed two shots per week. Considerable elevation of the level of dust is noted for zones 2 and 3, which can be explained by relation of this station to the access of the trucks to feed the primary crusher. The majority of the collected dust thus comes from open rock crushing of the rock and the receiving hopper of the product for

Table 1

Mechanical Characterization of the Rock

\begin{tabular}{|c|c|c|c|c|c|c|}
\hline Sample & Rock aspect & $\begin{array}{c}\text { Los Angeles Class } \\
(16 / 31.5)\end{array}$ & $\begin{array}{l}\text { Micro-Deval Humid } \\
\text { Class }(10 / 14)\end{array}$ & $\begin{array}{c}\text { Compressive } \\
\text { strength (MPa) }\end{array}$ & $\begin{array}{c}\text { Specific } \\
\text { weight }\left(\mathrm{t} / \mathrm{m}^{3}\right)\end{array}$ & $\begin{array}{c}\text { Apparent } \\
\text { density }\left(\mathrm{t} / \mathrm{m}^{3}\right)\end{array}$ \\
\hline S.01 & \multirow{5}{*}{$\begin{array}{l}\text { Gray granite with black } \\
\text { feldspar crystals and } \\
\text { white mica }\end{array}$} & 21.6 & 16.2 & \multirow[t]{3}{*}{184.8} & \multirow[t]{6}{*}{2.65} & \multirow[t]{6}{*}{2.52} \\
\hline S.02 & & 21.9 & 16.8 & & & \\
\hline S.03 & & 22.5 & 17.3 & & & \\
\hline S.04 & & 21.0 & 16.1 & \multirow[t]{2}{*}{184.2} & & \\
\hline S.05 & & 21.2 & 15.8 & & & \\
\hline Standard & & $\begin{array}{l}(\text { NFP } 18-572) \\
\text { LA } \leq 30\end{array}$ & $\begin{array}{l}(\text { NFP } 18-572) \\
M D E \leq 20\end{array}$ & & & \\
\hline
\end{tabular}

Table 2

The chemical composition of collected dusts

\begin{tabular}{|c|c|c|c|c|c|c|c|c|}
\hline Element & $\mathrm{SiO}_{2}$ & $\mathrm{CaO}$ & $\mathrm{Al}_{2} \mathrm{O}_{3}$ & $\mathrm{Fe}_{2} \mathrm{O}_{3}$ & $\mathrm{MgO}$ & $\mathrm{K}_{2} \mathrm{O}$ & $\mathrm{NaO}_{2}$ & $\mathrm{SO}_{3}$ \\
\hline$\%$ & 68.00 & 2.93 & 16.97 & 0.49 & 1.90 & 3.81 & 1.79 & 0.05 \\
\hline
\end{tabular}

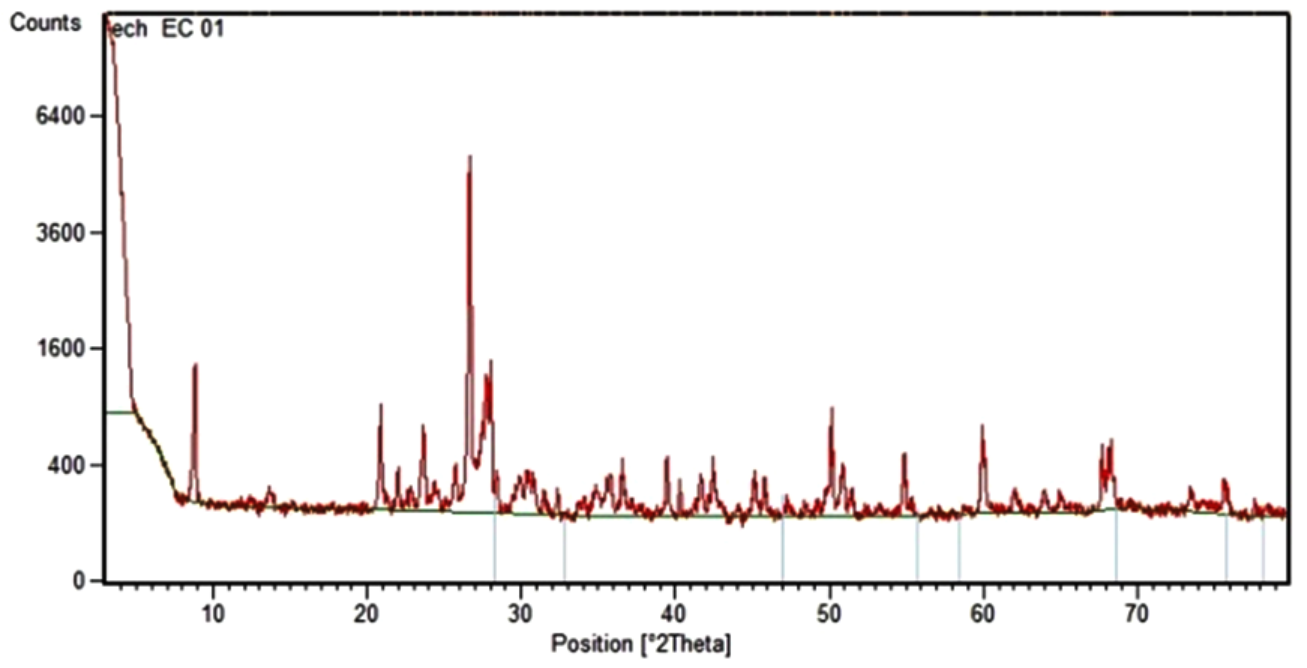

Fig. 5. XRD analysis of sample 

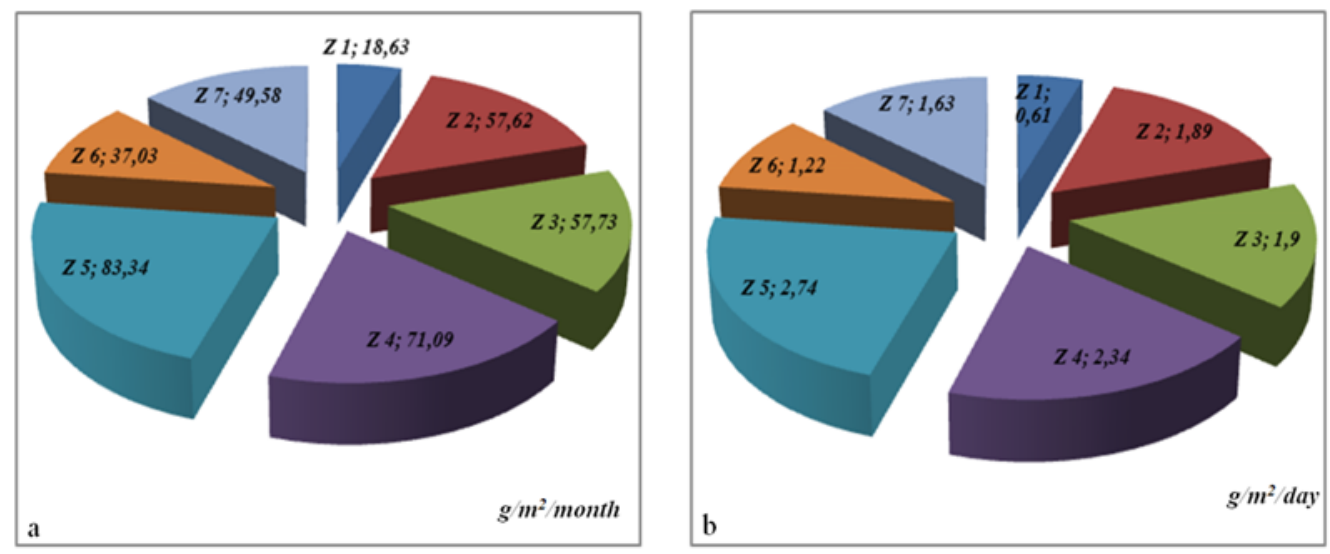

Fig. 6. Monthly and daily dust distribution:

$a-$ Monthly distribution; $b$ - Daily distribution

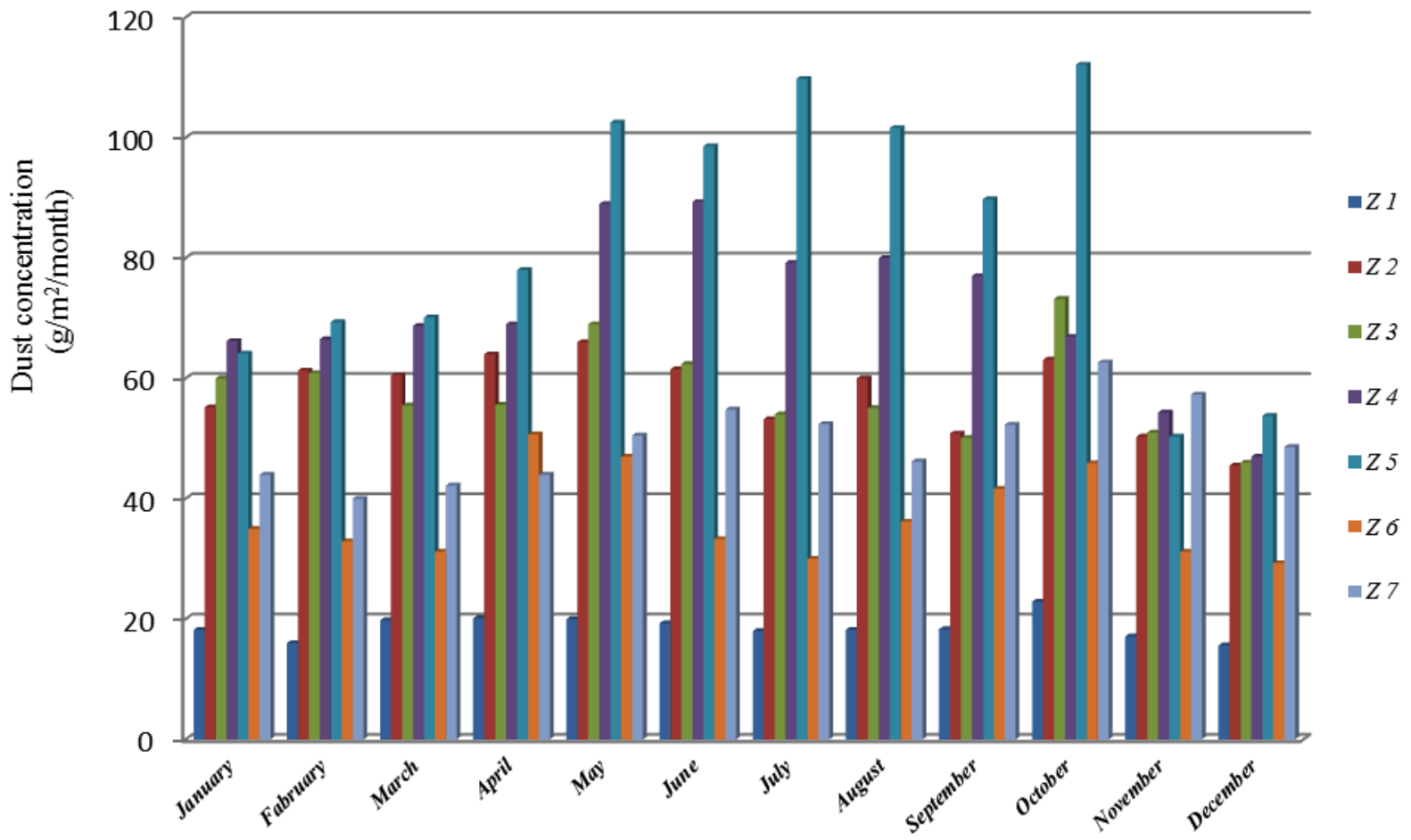

Fig. 7. Evolution of the dust level of the seven sampling zones

secondary crushing and storage of finished products. Zone 7 is located on the commercial site, where the traffic of the expedition trucks is a very important source of dusting the whole area.

Analysis of the initial state of the study area. In application of Decree 201-2019 of 29 December 2011, reforming impact studies, an analysis of the initial state of the quarry listed and described environments and elements capable to be affected by the project [12]. The interrelations between these elements and the evaluation of the sensitivity of the environment are presented in Table 3.

A close look at Table 3 shows that quarrying exploitation has harmful effects that have several consequences; it influences the climate and vegetation nearby watercourses and groundwater, whereas the dust suspended in the air is especially harmful to the health and safety of local populations.
The Algerian government has taken a number of measures within the framework of the preservation and protection of the environment as a strategic issue in its public policy in order to improve the companies' competitiveness [14].

The reduction and control of dust emissions related to mining activities can be achieved by taking certain measures, such as the proper maintenance of equipment, watering and development of different internal access tracks in dry periods [15].

Conclusion. The evaluation of dust in the study area shows that the operation of the quarry has negative effects on the environment.

It appears through these measurements, that the different sampling areas are characterized by a highly polluted zone, because of the high particulate benefits obtained (average of $83.34 \mathrm{~g} / \mathrm{m}^{2} / \mathrm{month}$ ) which is quite higher than 
Table 3 der the sponsorship of the Mineral Processing and En-

Interrelation between elements in the initial state

\begin{tabular}{|c|c|c|c|c|c|}
\hline \multirow{2}{*}{$\begin{array}{l}\text { Environmental } \\
\text { aspects }\end{array}$} & \multicolumn{5}{|c|}{$\begin{array}{l}\text { Evaluation of environmental } \\
\text { sensibility }\end{array}$} \\
\hline & Yes & No & Strong & Medium & weak \\
\hline \multicolumn{6}{|c|}{ Soil and subsoil } \\
\hline Agriculture & - & $\mathrm{x}$ & $\mathrm{x}$ & - & - \\
\hline Vegetation & - & $\mathrm{x}$ & $\mathrm{x}$ & - & - \\
\hline $\begin{array}{l}\text { Soil particularly } \\
\text { permeable }\end{array}$ & - & $\mathrm{x}$ & - & $\mathrm{x}$ & - \\
\hline $\begin{array}{l}\text { Pollution of soil and } \\
\text { subsoil }\end{array}$ & - & $\mathrm{x}$ & - & - & $\mathrm{x}$ \\
\hline Vicinity & - & $\mathrm{x}$ & - & - & $\mathrm{x}$ \\
\hline \multicolumn{6}{|c|}{ Water } \\
\hline Nearby watercourse & $\mathrm{x}$ & - & $\mathrm{x}$ & - & - \\
\hline $\begin{array}{l}\text { Zone of aquaculture } \\
\text { or fish culture }\end{array}$ & - & - & - & - & $\mathrm{x}$ \\
\hline $\begin{array}{l}\text { Proximity to a } \\
\text { tourist or leisure area }\end{array}$ & - & - & - & - & $\mathrm{x}$ \\
\hline Groundwater & $\mathrm{x}$ & & $\mathrm{x}$ & - & - \\
\hline $\begin{array}{l}\text { Site located in a } \\
\text { flood zone }\end{array}$ & - & $\mathrm{x}$ & $\mathrm{x}$ & - & - \\
\hline \multicolumn{6}{|c|}{ Air } \\
\hline $\begin{array}{l}\text { Relief causing poor } \\
\text { air circulation }\end{array}$ & - & $\mathrm{x}$ & - & - & $\mathrm{x}$ \\
\hline Heavily polluted area & $\mathrm{x}$ & - & $\mathrm{x}$ & - & - \\
\hline $\begin{array}{l}\text { Population/sensitive } \\
\text { area near }\end{array}$ & - & $\mathrm{x}$ & - & - & $\mathrm{x}$ \\
\hline Climate & $\mathrm{x}$ & - & $\mathrm{x}$ & - & - \\
\hline \multicolumn{6}{|c|}{ Noise } \\
\hline $\begin{array}{l}\text { Proximity to a } \\
\text { sensitive area } \\
\text { (Hospital, school) }\end{array}$ & - & $\mathrm{x}$ & - & - & $\mathrm{x}$ \\
\hline $\begin{array}{l}\text { Urban residential } \\
\text { area nearby }\end{array}$ & - & $\mathrm{x}$ & - & - & $\mathrm{x}$ \\
\hline
\end{tabular}

the reference value; $30 \mathrm{~g} / \mathrm{m}^{2} /$ month of the AFNOR NFX43-007 standard, as well as the indicator values derived from the German TA-LUFT standard $\left(10.5 \mathrm{~g} / \mathrm{m}^{2} / \mathrm{month}\right)$, and the Swiss OPair law $\left(6 \mathrm{~g} / \mathrm{m}^{2} / \mathrm{month}\right)$, which are more restrictive. It should be noted that for soils being dry and poor in vegetable tissue contribute to lifting and appearance of dust. This is clearly observed during measurements of dust contents. The establishment of a monitoring network and its exploitation will allow determining the potential for pollution in the pre-selected sites, and establishing a database to improve the living environment of citizens.

As for the periphery of the extraction zone, sedimentable dust emission controls are and will be carried out periodically involving the planning and implementation of a series of preventative measures to reduce and limit the impact of the project on the environment.

Acknowledgments. This research work was carried out at Badji Mokhtar University, Annaba, Algeria, un- vironmental Research Laboratory. The authors gratefully acknowledge all the colleagues who have contributed to realization of this paper.

\section{References.}

1. Azzeddine, M., 2015. L'acceptabilité sociale des projets miniers en Algérie: Cas de Ain Defla et Béjaia. European Scientific Journal, ESJ, 11(3), pp. 326-341.

2. Benselhoub, A., Kharytonov, M., Bouabdallah, S., Bounouala, M., Idres, A. and Boukelloul, M. L., 2015. Bioecological assessment of soil pollution with heavy metals in Annaba (Algeria). Studia Universitatis "Vasile Goldis” Arad. Seria Stiintele Vietii (Life Sciences Series), 25(1), pp. 17-22.

3. Benselhoub, A., Kharytonov, M., Chaabia, R. and Bdjoudj, S., 2015. Estimation of soil's sorption capacity to heavy metals in Algerian megacities: case of Algiers and Annaba. Mining science, 46(2), pp. 183-189.

4. Sid Ahmed, H. and Abdelhak, M., 2014. Contribution à l'étude des ressources minérales dans les monts des Traras (calcaire, sable et argile) état actuel, perspectives et impact sur l'environnement. PhD. Universite Abou Bekr Belkaid-Tlemcen.

5. Kharytonov, M., Benselhoub, A., Kryvakovska, R., Klimkina, I., Bouhedja, A., Bouabdallah, S. and Chaabia, R., 2017. Risk assessment of aerotechnogenic pollution generated by industrial enterprises in Algeria and Ukraine. Studia Universitatis Vasile Goldis Seria Stiintele Vietii (Life Sciences Series), 27(2), pp. 99-103.

6. Benselhoub, A., Kharytonov, M., Zaichenko, A. and Stankevich, S., 2015. Environmental Risks of ManMade Air Pollution in Grand Algiers. Journal of the Georgian Geophysical Society, Issue B. Physics of Atmosphere, Ocean and Space Plasma, 18B, pp. 43-51.

7. Kharytonov, M., Benselhoub, A., Klimkina, I., Bouhedja, A., Idres, A. and Aissi, A., 2016. Air pollution mapping in the Wilaya of Annaba (NE of Algeria). Mining Science, 23, pp. 183-189.

8. Henni-Chebra, K., Bougara, A. and Hallal, A., 2015. Estimation des particules de poussières causées par l'industrie cimentière par les plaques métalliques. $\mathrm{Na}$ ture and Technology, 12, pp. 2-10.

9. Soussia, T., Guedenon, P., Lawani, R., Gbaguidi, C. D. and Edorh, P.A., 2015. Assessment of Cement Dust Deposit in a Cement Factory in Cotonou (Benin). Journal of Environmental Protection, 6(07), pp. 675-682. 10. Campos, A., Matos, M. L., Góis, J., Vila, M. C., Dinis, M. L. and Baptista, J. S., 2014. Dispersion of quarry's dust-pilot study. Occupational Safety and Hygiene, II, pp. 21-29.

11. Broaddus, V.C., Mason, R.C., Ernst, J.D., King, T. E., Lazarus, S. C., Murray, J. F. and Gotway, M., 2015. Murray \& Nadel's Textbook of Respiratory Medicine E-Book. Elsevier Health Sciences.

12. Roger-Estrade, J., Maurice, S., Thomas-Vallejo, G., Aurenche, M. and Michelin, J., 2016. Methods for evaluating environmental impacts. Analysis and proposals. In: Peuportier, B., Leurent, F. and Roger-Estrade, J., eds., 2016. Eco-design of Buildings and Infrastructure. CRC Press, pp. 45-52. 
13. Lasalle, J.-L. and Malfait, F., 2017. Rapport Santé Environnement. Études Et Enquêtes Impact Sanitaire Du Site De Stockage De Mange-Garri Bouc-Bel-Air. Bouches-Du-Rhone.

14. Trirat, T., Brahamia, K. and Benselhoub, A., 2017. The issues of the implementation of an environmental management system ISO 14001 in the Algerian companies. Studia Universitatis Vasile Goldis Seria Stiintele Vietii (Life Sciences Series), 27(4), pp. 263-270.

15. Audit environnemental, 2014. Ministère de l'Aménagement du Territoire et de l'Environnement “MATE" Centre National des Technologies de Production plus Propre “C.N.T.P.P.” Mine de fer Boukhadra. Arcelormittal Tebessa, Algérie.

\section{Оцінка пилового забруднення на гранітному кар'єрі в Кеф Буасіда, м. Аннаба (Алжир)}

\section{А. Бутемеджет, М. Бунуала, А. Ідрес, А. Бенселгуб}

Університет Баджо Мохтар, м. Аннаба, Алжир, е-mail: boutemedjetassia@yahoo.fr

Мета. Оцінка пилового забруднення та аналіз повітряних частинок, що утворилися у процесі робіт на кар'єрі комплексу Кеф Буасіда, розташованого у Вель Ель Анебю, м. Аннаба, північно-східний Алжир.

Методика. Вимірювання й моніторинг опалого пилу, взятого на території кар'єру, дозволили визначити форми та характеристики зібраних частинок. Ці виміри були виконані згідно із французькими стандартами AFNOR NF X 43-007, а вимірювання сухих атмосферних осаджень - методом відкладення пластинок.

Результати. Результати, отримані під час випадіння пилу, показують, що ці вимірювання (83.34 г/м²/місяць) набагато вище, ніж початкове значення 30 г/ ${ }^{2} /$ місяць за стандартом AFNOR NF-X43-007, за німецьким стандартом TA-LUFT (10.5 г/м ${ }^{2} /$ місяць) і швейцарським законом OPair (6 г/м²/місяць). Тому запропоновані обмежуючі методи й заходи, спрямовані на обмеження, запобігання, а також усунення наслідків впливу даного виробництва на навколишнє середовище.

Наукова новизна. Оцінка несприятливого впливу, викликаного гірничорудним виробництвом, зокрема, шкідливий вплив пилу, може сприяти активізації боротьби з цими негативними впливами на навколишнє середовище, здоров'я та безпеку місцевого населення, а також посилити дії з охорони навколишнього середовища та сталому екологобезпечному розвитку.

Практична значимість. Скорочення викидів тонкодисперсних включень є однією з найбільш важливих екологічних проблем при видобутку корисних копалин в Алжирі. Оцінку впливу видобутку граніту на навколишнє середовище та опис складнощів при поширенні пилу можна проводити, покладаючись на заходи зменшення даного негативного впливу, що викликає проблеми із забезпеченням безпеки здоров'я працівників, прискорює знос устаткування та впливає на якість продукції, не рахуючи того, що ви- кликає труднощі для жителів і фермерів. Дане дослідження $є$ частиною проекту із захисту навколишнього середовища та збереження природних ресурсів.

Ключові слова: Алжир, пилове забруднення, вплив, навколишнє середовище, кар'єр Кеф Буасіда

\section{Оценка пылевого загрязнения на гранитном карьере в Кеф Буасида, г. Аннаба (Алжир)}

\section{А. Бутемеджет, М. Бунуала, А. Идрес, А. Бенселгуб}

Университет Баджи Мохтар, г. Аннаба, Алжир, e-mail: boutemedjetassia@yahoo.fr

Цель. Оценка пылевого загрязнения и анализ воздушных частиц, образовавшихся в процессе работ на карьере комплекса Кеф Буасида, расположенного в Вэль Эль Анеб, г. Аннаба, северо-восточный Алжир.

Методика. Измерения и мониторинг опавшей пыли, взятой с территории карьера, позволили определить формы и характеристики собранных частиц. Эти измерения были выполнены согласно французским стандартам AFNOR NF X 43-007, а измерения сухих атмосферных осаждений - методом отложения пластинок.

Результаты. Результаты, полученные во время выпадения пыли, показывают, что эти измерения (83.34 г/м ${ }^{2} /$ месяц) намного выше, чем исходное значение 30 г/м²/месяц по стандарту AFNOR NF-X43007, по немецкому стандарту TA-LUFT (10.5 г/M²/месяц) и швейцарскому закону OPair (6 г/м²/месяц). По этой причине предложены ограничивающие методы и меры, направленные на ограничение, предотвращение, а также устранение последствий влияния данного производства на окружающую среду.

Научная новизна. Оценка неблагоприятного воздействия, вызванного горнорудным производством, в частности, вредное воздействие пыли, может содействовать активизации борьбы с этими негативными влияниями на окружающую среду, здоровье и безопасность местного населения, а также усилить действия по охране окружающей среды и устойчивому экологобезопасному развитию.

Практическая значимость. Сокращение выбросов тонкодисперсных включений является одной из наиболее важных экологических проблем при добыче полезных ископаемых в Алжире. Оценку воздействия добычи гранита на окружающую среду и описание сложностей при распространении пыли можно проводить, полагаясь на меры уменьшения данного негативного воздействия, которое вызывает проблемы с обеспечением безопасности здоровья работников, ускоряет износ оборудования и влияет на качество продукции, не считая того, что вызывает затруднения для жителей и фермеров. Данное исследование является частью проекта по защите окружающей среды и сбережению природных ресурсов.

Ключевые слова: Алжир, пылевое загрязнение, влияние, окружающая среда, карьер Кеф Буасида

Рекомендовано до публікації Зохір Мекті. Дата надходження рукопису 18.01.18. 